\title{
Corrosion Inhibition for Mild Steel in Acidic Medium by Using Hexadecylamine as Corrosion Inhibitor
}

\author{
PRADEEP KUMAR $^{1}$, VIKAS KALIA ${ }^{1}$, HARISH KUMAR $^{2}$ and HARIOM DAHIYA ${ }^{1 *}$ \\ ${ }^{1}$ Department of Chemistry, M. D. University, Rohtak, Haryana-124001, India \\ ${ }^{2}$ Department of Chemistry, Ch. Devi Lal University, Sirsa, Haryana-125055, India \\ harichem2007@gmail.com
}

Received 4 June 2017 / Accepted 20 July 2017

\begin{abstract}
The corrosion study of mild steel in $1.0 \mathrm{M} \mathrm{HCl}$ solution at 298,308 and $318 \mathrm{~K}$ using various concentrations of hexadecylamine as corrosion inhibitor for different immersion time were carried out by weight loss technique and other different techniques i.e. Potentiodynamic polarization, Electrochemical impedance spectroscopy (EIS) at $298 \mathrm{~K}$ and SEM techniques. The adsorption of this molecule leads to the formation of a protective layer on mild steel. From the weight loss measurement the maximum percentage corrosion inhibition efficiency $96.26 \%$ was observed for $1000 \mathrm{ppm}$ concentration of inhibitor at $298 \mathrm{~K}$. By electrochemical impedance study it observed that charge transfer resistance $\left(R_{c t}\right)$ value increases and double layer capacitance $\left(C_{d 1}\right)$ value decreases with increasing the inhibitior concentration hence inhibition efficiency increases which related to the charge transfer resistance. From potentiodynamic polarization study it was observed that hexadecylamine behave as mixed type corrosion inhibitor. Adsorption of inhibitor on the mild steel surface is in agreement with the Langmuir adsorption isotherm. From the surface study it can be seen that on increasing the inhibitor concentration there is formation of protective layer on the surface of mild steel to protect the surface against corrosion and surface become smooth and more clean and clear. All above techniques study shows that hexadecylamine is a good corrosion inhibitor for mild steel in $1.0 \mathrm{M} \mathrm{HCl}$ solution.
\end{abstract}

Keywords: Mild steel, Hexadecylamine, $\mathrm{HCl}$, Potentiodynamic polarization, Electrochemical impedance spectroscopy, SEM

\section{Introduction}

Mild steel used mainly in industries and daily life uses due to its various properties like mechanical stress, easily availability and low cost price etc. It has been also used in formation of households, reaction vessel and storage $\operatorname{tank}^{1-2}$. Different type of acidic solutions mainly hydrochloric acid are widely used in industries in chemical cleaning, descaling and pickling, which lead to corrosive attack on such type steel ${ }^{3-6}$. Metals corroded usually in presence of oxygen and moisture and it involves two electrochemical processes i.e. oxidation occurs at anode and reduction at cathode. Corrosion can be controlled by 
suitable modification of the environment which in turn stifle, retard or completely stop the anodic or cathodic reactions or both type reactions. In the field of corrosion scientists play main role in control of corrosion of metals and alloys. Various methods are applied in protection of metals and alloy against corrosion. But the corrosion control by inhibitors were found one of the most common, effective and economic methods to protect metals against corrosion in acid medium. Therefore, the consumption of inhibitors to reduce corrosion has increased in recent years ${ }^{7}$. Corrosion inhibitors when added in small amount are more effective in corrosive medium to protect the metal against corrosion. The inhibition of corrosion in acid medium can be affected by a variety of organic, inorganic compounds and pharmaceutical drugs etc. Such Compounds those having $\mathrm{N}, \mathrm{O}$ and $\mathrm{S}$ have vast application as corrosion inhibitors ${ }^{8-16}$. The organic inhibitors are preferred over inorganic inhibitor as they contains electronegative group, $\pi$ electron in multiple bonds and aromatic ring in their structure, which act as the main adsorption centers ${ }^{17-19}$. The effectiveness of organic inhibitor also depends on electron density of donor sites, molecular weight of molecules, size and structure of inhibitor etc., ${ }^{20-23}$. Adsorption of inhibitors on mild steed surface is effective in cathodic and anodic processes and both type process. The first stage in the action mechanism of these compounds in acid media is their adsorption on the metal surface ${ }^{24}$. The Adsorption capacity of different substances constitutes an important feature to form a protective layer on metal surfaces and thus, these may be promoted as corrosion inhibitors for metals and alloys in various aggressive media ${ }^{25-31}$.

In continuation and literature survey to our earlier study ${ }^{32-37}$ show that amines and their derivative are effective corrosion inhibitors ${ }^{38-43}$. In the present study our aim to study the corrosion study of hexadecylamine for mild steel in $1.0 \mathrm{M} \mathrm{HCl}$ solution with different concentrations at different temperature for different time were analyzed by different techniques such as weight loss study, electrochemical impedance spectroscopy, potentiodynamic polarization technique, adsorption isotherm study and SEM (Scanning electron microscopy)

\section{Experimental}

Mild steel used for study having composition; C 0.054, Mn 0.26, Cr 0.056, Cu 0.010, Ti 0.002, S 0.017, P 0.019, Mo 0.018, Si 0.015, Ni 0.009 and remained iron. First of all the specimen were cut into $1 \times 3 \mathrm{~cm}^{2}$ dimensions for weight loss study and $1 \times 5 \mathrm{~cm}^{2}$ for electrochemical measurements and then polished with different grades of (100-1000) emery papers. Then specimens were rinsed with double distilled water, degreased with acetone and dried with help of hot air dryer and then used for the study.

\section{Inhibitor}

Hexadecylamine purchased from Sigma-Aldrich (99\%) was used as corrosion inhibitor for study. The molecular mass and molecular formula of hexadecylamine is $\mathrm{C}_{16} \mathrm{H}_{35} \mathrm{~N}$ and $241.463 \mathrm{~g} / \mathrm{mol}$ respectively. Structure of inhibitor is shown below (Scheme 1).

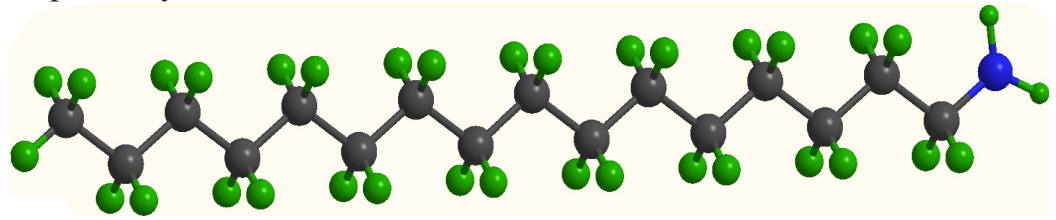

Scheme 1. Structure of Hexadecylamine 


\section{Preparation of solutions}

The corrosive medium i.e. acidic solution of $1.0 \mathrm{M} \mathrm{HCl}$ was prepared by dilution of conc. $\mathrm{HCl}$ analytical grade $37 \%$ with double distilled water. The inhibitor solution were made up by dilution of $0.5 \mathrm{~mL}$ hexadecylamine with $500 \mathrm{~mL}$ of $1.0 \mathrm{M} \mathrm{HCl}$ solution to make 1000 ppm solution (stock solution). The corrosion inhibitor used without any further purification. The concentrations range was used for experimentation from $0 \mathrm{ppm}$ to $1000 \mathrm{ppm}$ with a difference of $200 \mathrm{ppm}$. The desired concentrations of hexadecylamine were made from stock solution of $1000 \mathrm{ppm}$.

\section{Weight loss measurement}

The gravimetric method (weight loss measurement) is probably the most widely used method of inhibition assessment. The simplicity and reliability of the measurement offered by the weight loss method are such that the technique forms the baseline method of measurement in many corrosion monitoring programmers. The weight loss study has been carried out in $1.0 \mathrm{M} \mathrm{HCl}$ solution. First of all mild steel samples were cut in to $1 \times 3 \mathrm{~cm}^{2}$ then abraded with emery paper of different grade (100-1000) and rinsed with double distilled water, cleaned with acetone and finally dried between filter paper then weighed. The weight loss study carried out at on previously weighed sample in $30 \mathrm{~mL}$ of $1.0 \mathrm{M} \mathrm{HCl}$ solution filled in $50 \mathrm{~mL}$ beaker in presence and absence of various concentrations of inhibitor for 12 , 18 and $24 \mathrm{~h}$ at different temperature ranges i.e. 298,308 and $318 \mathrm{~K}$ in test solution and then sample put out side from the test solution after completion of time and cleaned with double distilled water followed by acetone, dried then weighed again. This weight loss study was performed in triplicate and then average weight loss was recorded by this weight loss study. Percentage corrosion inhibition efficiency and surface coverage was calculated by following equations.

$$
\begin{gathered}
\eta_{w} \%=\frac{\mathrm{w}_{\mathrm{o}}-\mathrm{w}_{\mathrm{i}}}{\mathrm{w}_{\mathrm{o}}} \times 100 \\
\theta=\frac{\mathrm{w}_{\mathrm{o}}-\mathrm{w}_{\mathrm{i}}}{\mathrm{w}_{\mathrm{o}}}
\end{gathered}
$$

Where, $\mathrm{w}_{\mathrm{o}}$ and $\mathrm{w}_{\mathrm{i}}$ are the weight loss value of mild steel in absence and presence of inhibitor respectively. The corrosion rate of mild steel was calculated by using equation (3)

$$
\mathrm{C}_{\mathrm{R}}\left(\mathrm{mmy}^{-1}\right)=\frac{87.6 \times w}{A t D}
$$

Where $\mathrm{w}$ is weight loss of mild steel in $\mathrm{mg}$, A is area of sample $\left(\mathrm{cm}^{2}\right), \mathrm{t}$ is exposure time (hours) and D is density of mild steel $\left(\mathrm{g} \mathrm{cm}^{-3}\right)$.

\section{Electrochemical measurement}

Mild steel samples size of $1 \times 5 \mathrm{~cm}^{2}$ dimensions were used for electrochemical study. The mild steel samples were rubbed with (100-1000) grades of emery papers, cleaned with double distilled water followed by acetone and dried put into desiccators then used for experimental study. The sample surface area $1.0 \times 1.0 \mathrm{~cm}^{2}$ has been selected for the electrochemical study. Electrochemical impedance and potentiodynamic polarization were carried out by AUTOLAB salatron model 1280B potentiostat. Electrochemical process were carried out with help of three electrodes, one of them is mild steel as working electrode, platinum as counter electrode and saturated calomel electrode as reference electrode were suspended in $50 \mathrm{~mL}$ beaker with different concentrations (200-1000 ppm) of hexadecylamine prepared by $1.0 \mathrm{M} \mathrm{HCl}$ solution. Before starting each experiments first of all the electrodes were 
immersed in test solution at open circuit potential (OCP) for 30 minutes at $298 \mathrm{~K}$ temperature to attain a stabilized value of OCP and then proceeded the measurement.

\section{Electrochemical impedance spectroscopy}

The impedance measurements were carried out in frequency range of $10 \mathrm{kHz}$ to $0.01 \mathrm{~Hz}$ with signal amplitude of $10 \mathrm{mV}$ at the corrosion potential $\left(-\mathrm{E}_{\text {corr }}\right)$. The experiments were performed with different concentrations of inhibitor which were previously used in weight loss experiments. All impedance measurements were automatically controlled by $Z$-view software and the impedance diagrams were given in the Nyquist representation. Electrochemical impedance parameters such as charge transfer resistance $\left(\mathrm{R}_{\mathrm{ct}}\right)$ and double layer capacitance $\left(\mathrm{C}_{\mathrm{dl}}\right)$ were calculated from EIS data ${ }^{44}$.

\section{Potentiodynamic polarization}

The electrochemical corrosion behavior of mild steel sample in presence and absence of different concentrations of inhibitor in $1.0 \mathrm{M} \mathrm{HCl}$ solution at $298 \mathrm{~K}$ was carried out by the potentiodynamic polarization curves. The polarization study was taken after impedance measurement at same cell setup and potential range were taken $-200 \mathrm{mV}$ to $+200 \mathrm{mV}$ with respect to open circuit potential, at a scan rate of $1.0 \mathrm{mV} / \mathrm{s}$. From the polarization curves, the corrosion parameters such as corrosion potential $\left(-\mathrm{E}_{\text {corr }}\right)$, corrosion current density $\left(\mathrm{I}_{\text {corr }}\right)$, cathodic $\left(\beta_{\mathrm{c}}\right)$ and anodic $\left(\beta_{\mathrm{a}}\right)$ Tafel constant were obtained.

\section{SEM analysis}

After immersion of mild steel samples in $1.0 \mathrm{M} \mathrm{HCl}$ in the absence and presence of hexadecylamine at different temperatures for $24 \mathrm{~h}$, the surface morphology of samples were performed on a ZEISS scanning electronic microscope (AIIMS, DELHI).

\section{Results and Discussion}

\section{Weight loss study}

Corrosion inhibition performance of hexadecylamine as corrosion inhibitors can be evaluated by using weight loss study of mild steel which was determined at various interval of time in absence and presence of different concentrations of inhibitor. Weight loss provides more reliable results than electrochemical techniques for the determination of corrosion inhibition efficiency.

\section{Effect of immersion time}

The experiments carried out in $1.0 \mathrm{M} \mathrm{HCl}$ solution with different concentration of hexadecylamine at different temperatures for different time i.e. 12, 18 and $24 \mathrm{~h}$. The variations of inhibition efficiency and corrosion rate with immersion time at different temperatures are shown in Figures $1 \mathrm{a}-\mathrm{c}$ and $2 \mathrm{a}-\mathrm{c}$. It can be observed from the figures that with increasing the immersion time the inhibition efficiency increased and corrosion rates decreased at same temperature. This is because of increased the adsorption process on mild steel surface at higher immersion time.

\section{Effect of concentration}

The values of inhibition efficiency and corrosion rate with different concentrations of inhibitor in acidic solution at different temperatures after various immersion times are summarized in Tables 1, 2 and 3. Data from tables revealed that the percentage inhibition efficiency increased and corrosion rates decreased with increasing the concentration of inhibitor. 
The maximum inhibition efficiency was found to be $96.26 \%$ for higher concentration of inhibitor (1000 ppm) at $298 \mathrm{~K}$ temperature for $24 \mathrm{~h}$. It might be due to increasing adsorption of hexadecylamine on the mild steel surface with concentration.

\section{Effect of temperature}

From the inspection of tables and figures it was observed that with rise in temperature from $298 \mathrm{~K}$ to $318 \mathrm{~K}$ the weight loss of mild steel increased hence the inhibition efficiency value decreased but corrosion rates value increased at same concentration of inhibitor. According to Oguzie et $a l^{45}$, a decrease of inhibition efficiency with rise in temperature suggests that inhibitor molecules are physically adsorbed on the metal surface, while the reverse behavior suggests the molecules absorbed surface by the action of hemisorptions. Thus, the results signify that the adsorption of hexadecylamine is mainly due to the physical adsorption. The increase in temperature usually accelerates the evolution of hydrogen, which results in a higher dissolution rate of the mild steel. The decrease in inhibition efficiency with temperature may be due to desorption of the inhibitor molecule.
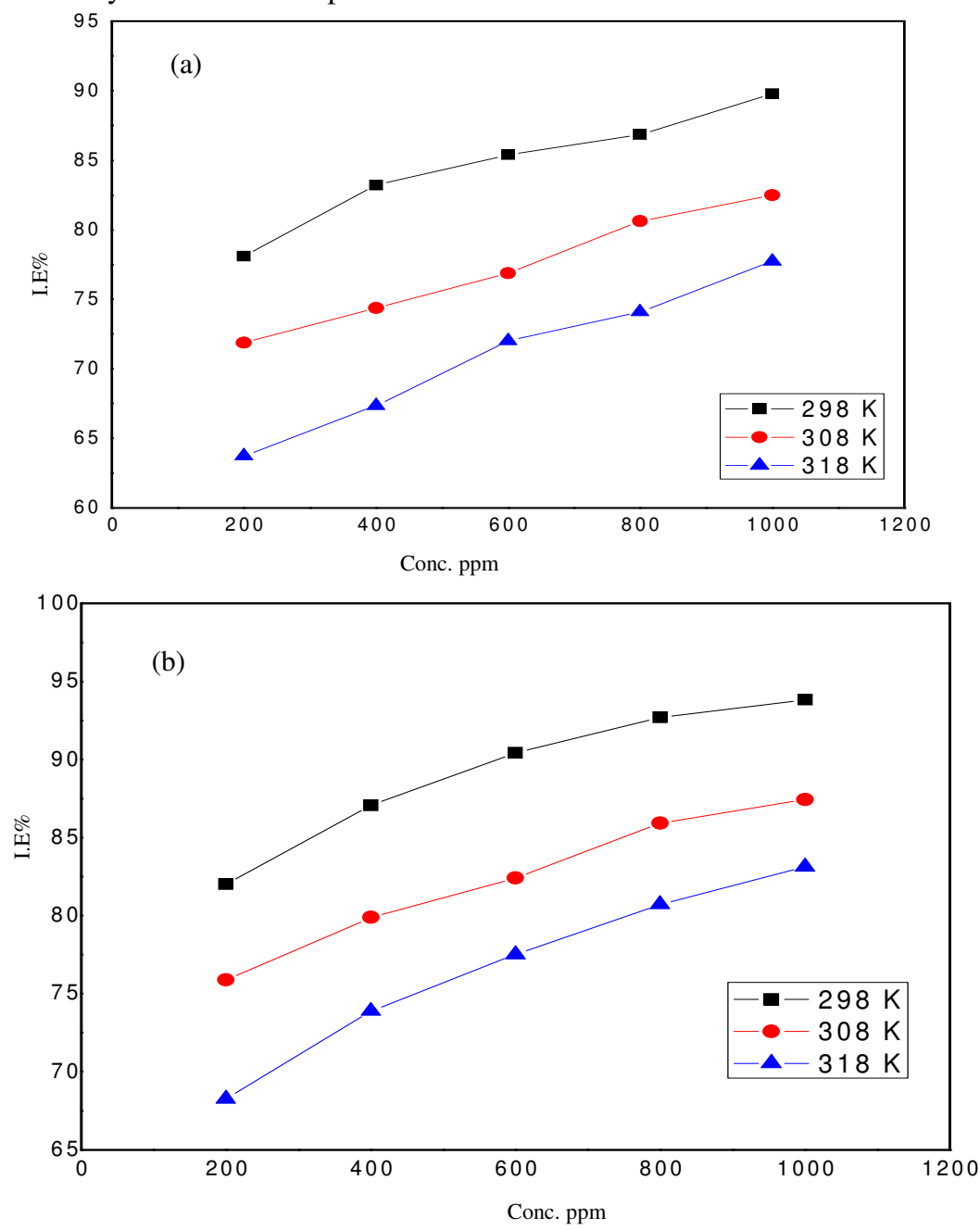


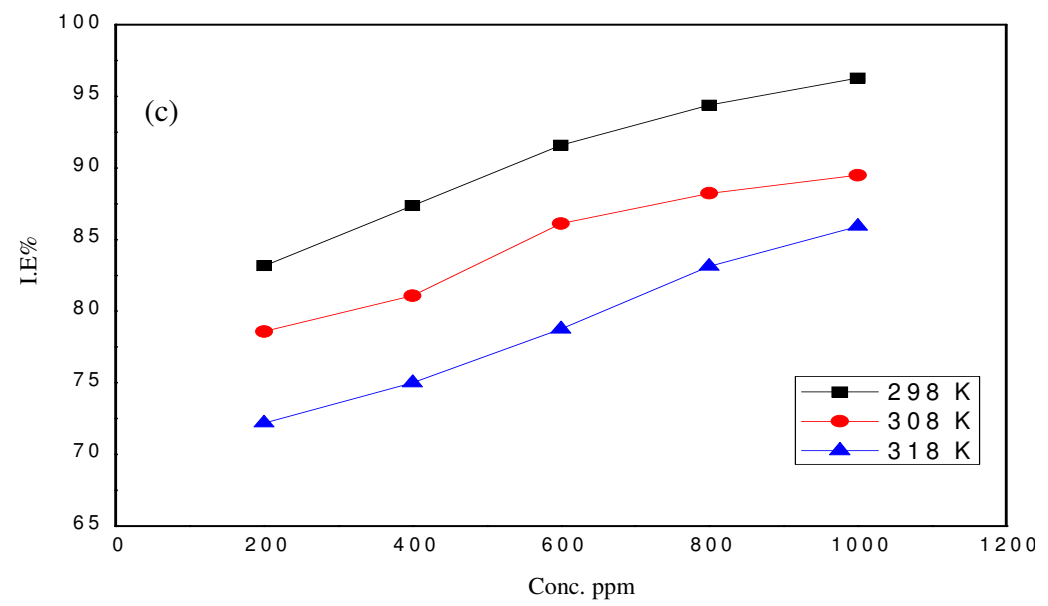

Figures 1a-c. Inhibition efficiency graph for mild steel with various concentrations of hexadecylamine at 298, 308 and $318 \mathrm{~K}$ for different immersion time (a) $12 \mathrm{~h}$ (b) $18 \mathrm{~h}$ and (c) $24 \mathrm{~h}$
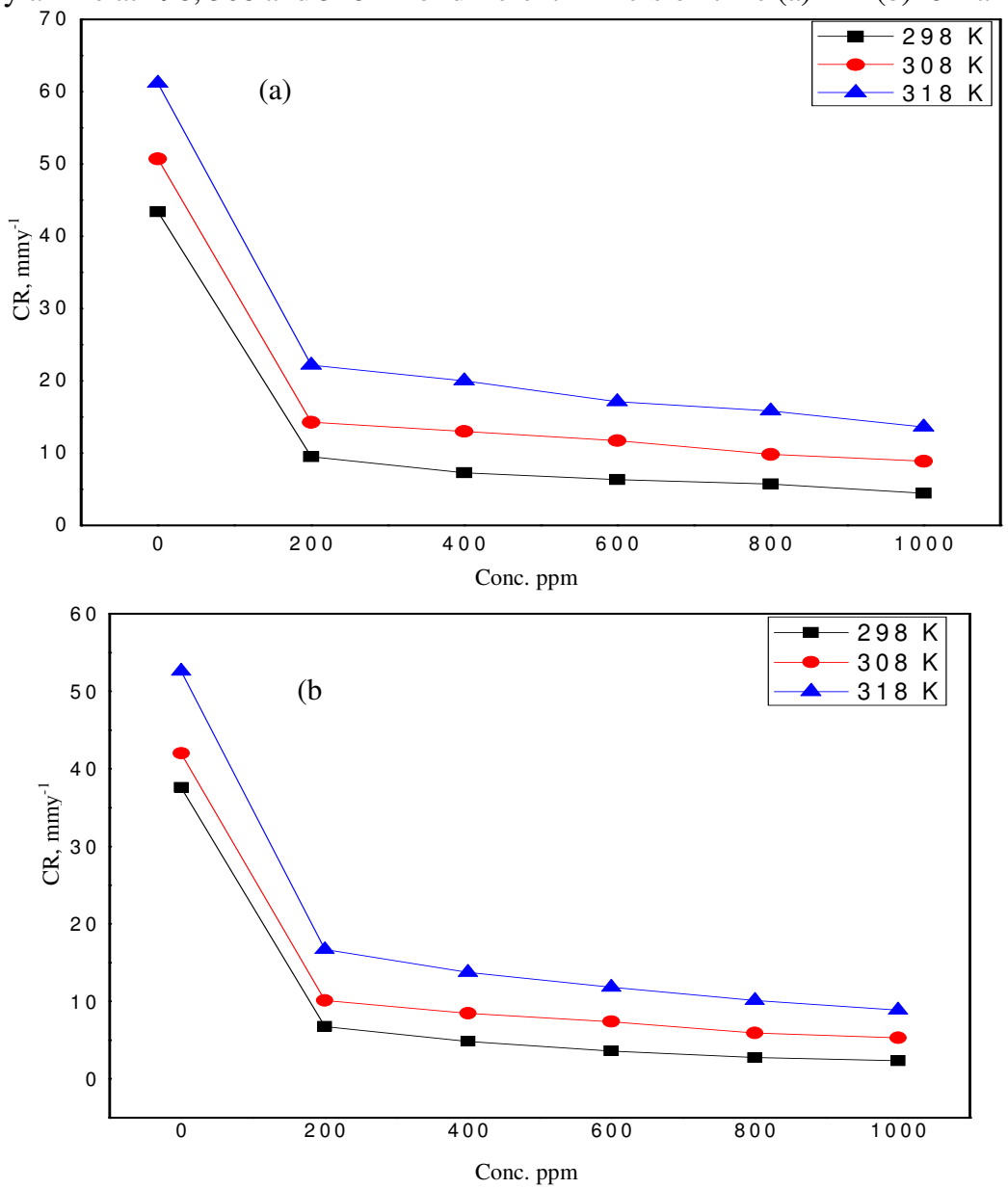


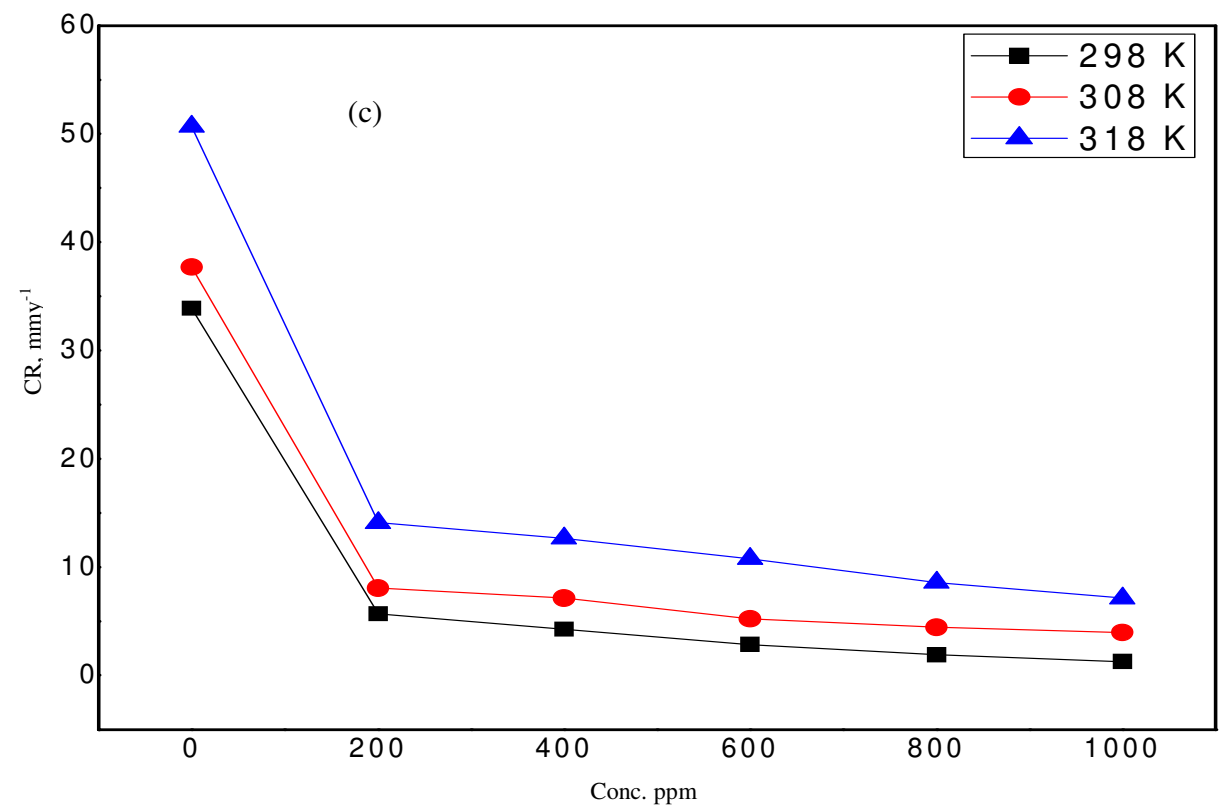

Figures 2a-c. Corrosion graph for mild steel with various concentrations of hexadecylamine at 298, 308 and $318 \mathrm{~K}$ for different immersion time (a) $12 \mathrm{~h}$ (b) $18 \mathrm{~h}$ and (c) $24 \mathrm{~h}$

Table 1. Inhibition efficiency values for the corrosion of mild steel in acid solution of $1.0 \mathrm{M}$ $\mathrm{HCl}$ in the absence and in the presence of different concentrations of hexadecylamine from weight loss measurements at $298 \mathrm{~K}$ for 12,18 and $24 \mathrm{~h}$ of immersion time

\begin{tabular}{ccccccc}
\hline $\begin{array}{c}\text { Inhibitor } \\
\text { name }\end{array}$ & $\begin{array}{c}\text { Concentration, } \\
\mathrm{ppm}\end{array}$ & $\begin{array}{c}\text { Weight } \\
\text { Before, g }\end{array}$ & $\begin{array}{c}\text { Weight } \\
\text { After, g }\end{array}$ & $\begin{array}{c}\text { Weight } \\
\text { loss, g }\end{array}$ & $\begin{array}{c}\text { Corrosion } \\
\text { Rate } \\
\text { mmy }^{-1}\end{array}$ & $\begin{array}{c}\text { Inhibition } \\
\text { efficiency, } \\
\eta w \%\end{array}$ \\
\hline $\begin{array}{c}\text { Hexa } \\
\text { decylamine }\end{array}$ & 0 & 1.109 & 0.972 & 0.137 & 43.40 & - \\
$(12 \mathrm{~h})$ & 200 & 1.114 & 1.084 & 0.030 & 9.50 & 78.10 \\
& 600 & 1.099 & 1.076 & 0.023 & 7.28 & 83.21 \\
& 800 & 1.101 & 1.081 & 0.020 & 6.33 & 85.40 \\
$(18 \mathrm{~h})$ & 1000 & 1.113 & 1.095 & 0.018 & 5.70 & 86.86 \\
& 0 & 1.127 & 1.103 & 0.014 & 4.43 & 89.78 \\
& 200 & 1.093 & 1.061 & 0.032 & 6.75 & 82.02 \\
& 400 & 1.120 & 1.097 & 0.023 & 4.85 & 87.07 \\
& 600 & 1.080 & 1.063 & 0.017 & 3.59 & 90.44 \\
$(24 \mathrm{~h})$ & 800 & 1.111 & 1.098 & 0.013 & 2.74 & 92.69 \\
& 1000 & 1.126 & 1.115 & 0.011 & 2.32 & 93.82 \\
& 0 & 1.117 & 0.903 & 0.214 & 33.90 & - \\
& 200 & 1.110 & 1.074 & 0.036 & 5.70 & 83.17 \\
& 400 & 1.113 & 1.086 & 0.027 & 4.27 & 87.38 \\
& 600 & 1.106 & 1.088 & 0.018 & 2.85 & 91.58 \\
& 800 & 1.108 & 1.096 & 0.012 & 1.90 & 94.39 \\
& 1000 & 1.122 & 1.114 & 0.008 & 1.26 & 96.26 \\
\hline
\end{tabular}


Table 2. Inhibition efficiency values for the corrosion of mild steel in acid solution of $1.0 \mathrm{M}$ $\mathrm{HCl}$ solution in the absence and in the presence of different concentrations of hexadecylamine from weight loss measurements at $308 \mathrm{~K}$ for 12,18 and $24 \mathrm{~h}$ of immersion time

\begin{tabular}{ccccccc}
\hline $\begin{array}{c}\text { Inhibitor } \\
\text { name }\end{array}$ & $\begin{array}{c}\text { Concentration, } \\
\text { ppm }\end{array}$ & $\begin{array}{c}\text { Weight } \\
\text { before, } \\
\mathrm{g}\end{array}$ & $\begin{array}{c}\text { Weight } \\
\text { after, g }\end{array}$ & $\begin{array}{c}\text { Weight } \\
\text { loss, g }\end{array}$ & $\begin{array}{c}\text { Corrosion } \\
\text { rate, } \\
\text { mmy }\end{array}$ & $\begin{array}{c}\text { Inhibition } \\
\text { efficiency, } \\
\eta w \%\end{array}$ \\
\hline $\begin{array}{c}\text { Hexa } \\
\text { decylamine }\end{array}$ & 0 & 1.137 & 0.977 & 0.160 & 50.69 & - \\
$(12 \mathrm{~h})$ & 400 & 1.115 & 1.070 & 0.045 & 14.25 & 71.87 \\
& 600 & 1.165 & 1.124 & 0.041 & 12.99 & 74.37 \\
& 800 & 1.097 & 1.060 & 0.037 & 11.72 & 76.87 \\
$(18 \mathrm{~h})$ & 1000 & 1.134 & 1.103 & 0.031 & 9.82 & 80.62 \\
& 0 & 1.120 & 1.099 & 0.028 & 8.87 & 82.50 \\
& 200 & 1.109 & 1.060 & 0.048 & 10.13 & 75.87 \\
& 400 & 1.126 & 1.086 & 0.040 & 8.44 & 79.89 \\
& 600 & 1.096 & 1.061 & 0.035 & 7.39 & 82.41 \\
$(24 \mathrm{~h})$ & 100 & 1.124 & 1.096 & 0.028 & 5.91 & 85.93 \\
& 000 & 1.118 & 1.093 & 0.025 & 5.28 & 87.43 \\
& 200 & 1.137 & 0.899 & 0.238 & 37.70 & - \\
& 400 & 1.147 & 1.096 & 0.051 & 80.7 & 78.57 \\
& 600 & 1.125 & 1.080 & 0.045 & 7.12 & 81.09 \\
& 800 & 1.118 & 1.085 & 0.033 & 5.22 & 86.13 \\
& 1000 & 1.121 & 1.101 & 0.028 & 4.43 & 88.23 \\
& 1006 & 0.025 & 3.96 & 89.49 \\
\hline
\end{tabular}

Table 3. Inhibition efficiency values for the corrosion of mild steel in acid solution of $1.0 \mathrm{M}$ $\mathrm{HCl}$ in the absence and in the presence of different concentrations of hexadecylamine from weight loss measurements at $318 \mathrm{~K}$ for 12,18 and $24 \mathrm{~h}$ of immersion time

\begin{tabular}{ccccccc}
\hline $\begin{array}{c}\text { Inhibitor } \\
\text { name }\end{array}$ & $\begin{array}{c}\text { Concentration, } \\
\mathrm{ppm}\end{array}$ & $\begin{array}{c}\text { Weight } \\
\text { Before, } \\
\mathrm{g}\end{array}$ & $\begin{array}{c}\text { Weight } \\
\text { After, }\end{array}$ & $\begin{array}{c}\text { Weight } \\
\text { loss, g }\end{array}$ & $\begin{array}{c}\text { Corrosion } \\
\text { rate, } \\
\text { mmy }^{-1}\end{array}$ & $\begin{array}{c}\text { Inhibition } \\
\text { efficiency, } \\
\eta w \%\end{array}$ \\
\hline $\begin{array}{c}\text { Hexa } \\
\text { decylamine }\end{array}$ & 0 & 1.140 & 0.957 & 0.193 & 61.15 & - \\
$(12 \mathrm{~h})$ & 400 & 1.128 & 1.058 & 0.070 & 22.17 & 63.73 \\
& 600 & 1.120 & 1.057 & 0.063 & 19.96 & 67.35 \\
& 800 & 1.100 & 1.046 & 0.054 & 17.10 & 72.02 \\
& 1000 & 1.140 & 1.090 & 0.050 & 15.84 & 74.09 \\
$(18 \mathrm{~h})$ & 0 & 1.087 & 1.071 & 0.043 & 13.62 & 77.72 \\
& 200 & 1.120 & 1.041 & 0.249 & 52.59 & - \\
& 400 & 1.100 & 1.035 & 0.079 & 16.68 & 68.27 \\
& 600 & 1.097 & 1.041 & 0.056 & 13.72 & 73.89 \\
& 800 & 1.117 & 1.069 & 0.048 & 10.13 & 80.72 \\
& 1000 & 1.125 & 1.083 & 0.042 & 8.87 & 83.13 \\
& 0 & 1.148 & 0.828 & 0.320 & 50.69 & - \\
& 200 & 1.108 & 1.019 & 0.089 & 14.09 & 72.18 \\
& 400 & 1.101 & 1.021 & 0.080 & 12.67 & 75.00 \\
& 600 & 1.152 & 1.084 & 0.068 & 10.77 & 78.75 \\
& 800 & 1.155 & 1.101 & 0.054 & 8.55 & 83.12 \\
& 1000 & 1.129 & 1.084 & 0.045 & 7.12 & 85.93 \\
\hline
\end{tabular}




\section{Adsorption isotherm}

To understand the effect of inhibitor on mild steel surface, the study of adsorption isotherm is very important aspect. Several isotherm can be used to analyze the adsorption behavior of inhibitor on the surface i.e., Temkin, Frumkin, Freundlich, Flory - Huggins and Langmuir isotherm etc. But among them the studied experimental data was found to be fitted by Langmuir's adsorption isotherm.

A straight line curve with strong correlation coefficient nearly equal to 1.0 was obtained on plotting $\mathrm{C}_{\text {inhi/ }} / \Theta$ against $\mathrm{C}_{\mathrm{inh}}$ as shown in Figures 3a-c also suggesting that adsorption of the compound on the mild steel surface followed Langmuir adsorption isotherm model. The relation between surface coverage $\theta$ and the inhibitor concentration is given by Langmuir's adsorption isotherm ${ }^{46-47}$.

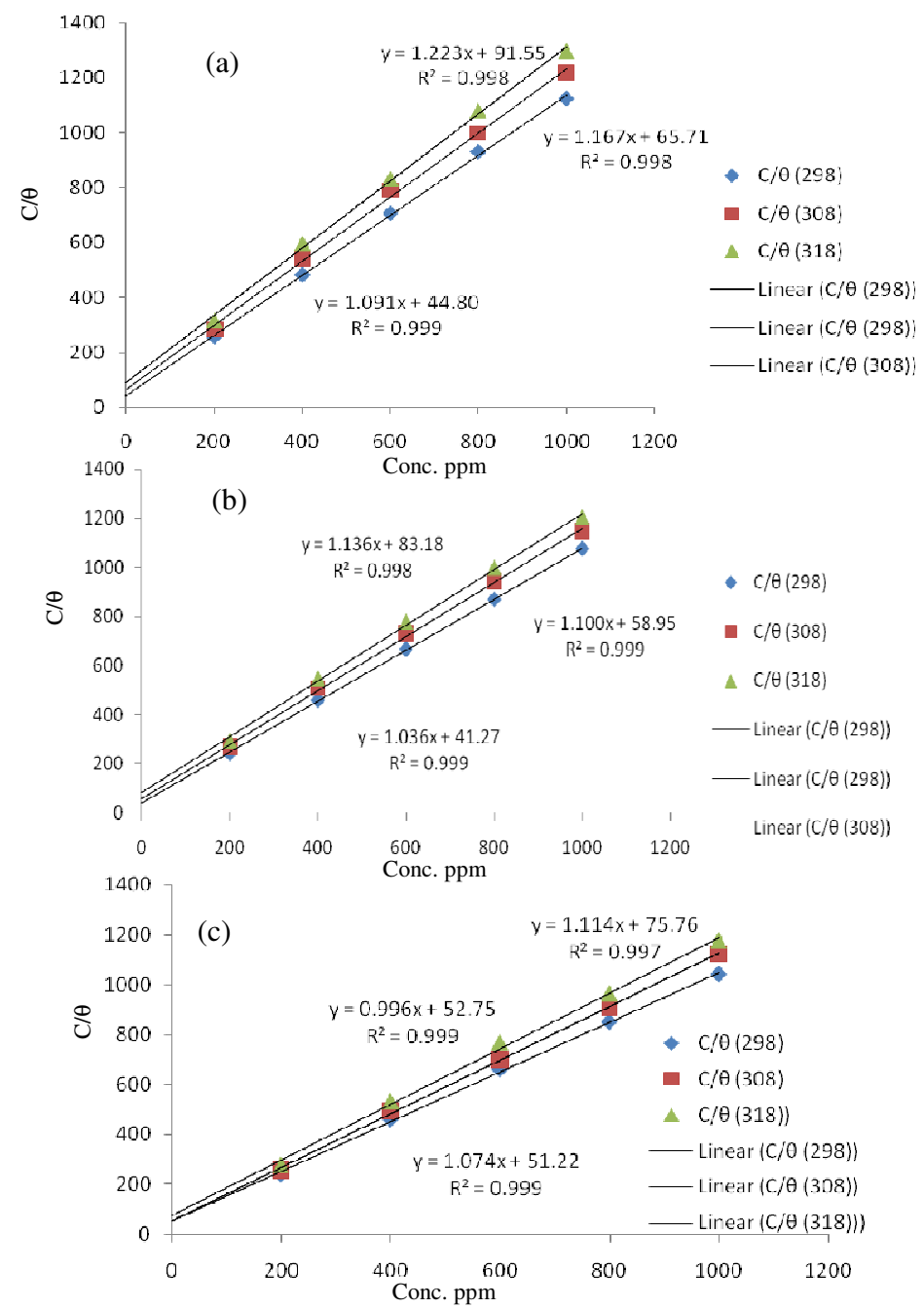

Figures 3(a-c). Langmuir adsorption isotherm plot for the mild steel in $1.0 \mathrm{M} \mathrm{HCl}$ solution with different concentration of hexadecylamine at different temperatures for immersion time (a) $12 \mathrm{~h} \mathrm{(b)} 18 \mathrm{~h}$ and (c) $24 \mathrm{~h}$ 


$$
\frac{C_{i n h}}{\theta}=\frac{1}{K_{a d s}}+C
$$

Where, $C_{i n h}$ is the concentration of inhibitor, $\theta$ is the surface coverage which is obtained from the weight loss by using equation $\theta=\frac{w_{o}-w_{i}}{w_{o}}$ and $K_{a d s}$ could be calculated from the intercepts of the straight lines on the $\frac{C_{i n h}}{\theta}$ axis; the equilibrium constant of the adsorption relation to the standard free adsorption energy is calculated from the equilibrium constant using following equation:

$$
\Delta G^{0}{ }_{a d s}=-R T\left(\ln 55.5 K_{a d s}\right)
$$

Where, $\mathrm{R}$ is the universal gas constant $\left(8.314 \mathrm{~J} \mathrm{~mol}^{-1} \mathrm{~K}^{-1}\right), \mathrm{T}$ is absolute temperature and 55.5 is the concentration of water ${ }^{48-49}$ in solution $(\mathrm{mol} / \mathrm{L})$. The linear correlation coefficient adsorption parameters $\mathrm{K}_{\mathrm{ads}}$ and $\Delta \mathrm{G}^{0}$ ads values are illustrate in Table 4 . It reveals that with increasing temperature the $\mathrm{K}_{\mathrm{ads}}$ decreases gradually, which indicates that the inhibitor strongly adsorbed on to the steel surface at a lower temperature. But when the temperature is high, the adsorbed inhibitor tends to desorbed from the steel surface. Generally, the absolute value of $\Delta \mathrm{G}_{\text {ads }}^{0}$ is $-20 \mathrm{~kJ} / \mathrm{mol}$ lower than $-20 \mathrm{~kJ} / \mathrm{mol}$, they are consistent with the electrostatic interaction between the charged molecules and the charged metal called physical adsorption (physisorption); when those that are $-40 \mathrm{~kJ} / \mathrm{mol}$ or more negative than $-40 \mathrm{~kJ} / \mathrm{mol}$, which involve sharing or transfer of electrons from the inhibitor molecules to the metal surface to form a coordinate bond called chemical adsorption (chemisorption) $)^{50-52}$. Here, the calculated value of $\Delta \mathrm{G}_{\text {ads }}^{0}$ for hexadecylamine from table are found to be ranged from -25.40 to $-26.08 \mathrm{~kJ} \mathrm{~mol}^{-1}$ for different immersion time which indicate that the adsorption process of inhibitor on metal surface is mixed physical and chemical adsorption called physiochemical adsorption ${ }^{53-55}$. Also the negative values of $\Delta G^{0}$ ads revealed that the adsorption of inhibitor on to the mild steel is a spontaneous process usually shows the strong interaction on the surface.

Table 4. Thermodynamic adsorption parameters for mild steel in $1.0 \mathrm{M} \mathrm{HCl}$ in the presence of various concentration of hexadecylamine at different temperatures

\begin{tabular}{cccc}
\hline Inhibitor name & Temp., $\mathrm{k}$ & $\log 55.5 \mathrm{~K}_{\mathrm{ads}}$ & $\Delta \mathrm{G}_{\mathrm{ads}}^{0}, \mathrm{~kJ} \mathrm{~mol}^{-1}$ \\
\hline \multirow{2}{*}{ Hexadecylamine } & 298 & 4.482 & -25.574 \\
$12 \mathrm{~h}$ & 308 & 4.315 & -25.451 \\
& 318 & 4.171 & -25.401 \\
\multirow{2}{*}{$18 \mathrm{~h}$} & 298 & 4.517 & -25.777 \\
& 308 & 4.362 & -25.729 \\
\multirow{2}{*}{$24 \mathrm{~h}$} & 318 & 4.213 & -25.654 \\
& 298 & 4.411 & -25.169 \\
& 308 & 4.424 & -26.089 \\
\hline
\end{tabular}

\section{Electrochemical impedance spectroscopy measurement}

Through the impedance spectroscopy study the results obtained are presented in the form of nyquist plot for mild steel in $1.0 \mathrm{M} \mathrm{HCl}$ in the presence and absence of different concentrations 
of inhibitor is shown in Figure 4. The Nyquist plot are semicircle in nature and it can be seen from the diagram that diameter of semicircle increases with increasing the inhibitor concentration in $1.0 \mathrm{M} \mathrm{HCl}$ solution. It shows that the impedance of mild steel is increased with increasing in concentration of inhibitor and also shows adsorption of inhibitor on surface of mild steel. The impedance spectra show the one single capacitive loop which suggest that the corrosion of mild steel surface is mainly controlled by the charge transfer process and generally related to charge transfer and double layer behavior ${ }^{56-57}$.

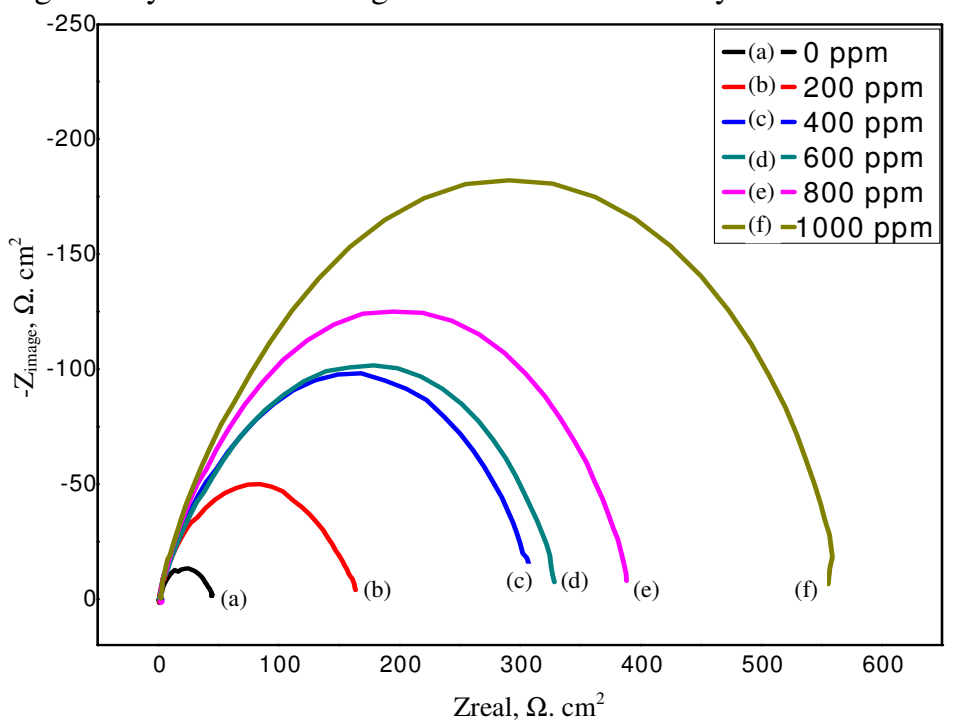

Figure 4. Nyquist plot for mild steel in $1.0 \mathrm{M} \mathrm{HCl}$ in different concentration of hexadecylamine as corrosion inhibitor

All the impedance parameters that are obtained from impedance such as charge transfer resistance $\left(\mathrm{R}_{\mathrm{ct}}\right)$, double layer capacitance $\left(\mathrm{C}_{\mathrm{dl}}\right)$ and inhibition efficiency are shown in Table 5 . The value obtained for charge transfer resistance $\left(R_{c t}\right)$ was calculated from the difference in impedance $\left(Z_{\text {real }}\right)$ lower and higher frequencies. From the Table it has shown that the charge transfer resistance $\left(\mathrm{R}_{\mathrm{ct}}\right)$ value increased with increasing the concentration of inhibitor in the solution. The decrease in $\mathrm{C}_{\mathrm{dl}}$ (double layer capacitance) with increasing the concentration of inhibitor indicating that increase the thickness of electrical double layer which denote the inhibitor molecule function by adsorption at the metal/ solution interface ${ }^{58}$. The value of double layer capacitance are calculated from the frequency at which the imaginary component of impedance is $\left(-Z_{\max }\right)$ maximal and $R_{c t}$ value by using following equation ${ }^{59,37}$.

$$
C_{d l}=\frac{1}{2 \pi f_{\max } R_{c t}}
$$

Where, $f_{\max }$ is the frequency value at the top of semicircle of $Z_{\text {real }}$ axis and $R_{c t}$ is the charge transfer resistance with inhibitior concentration, respectively.

The $R_{c t}$ value is used to calculate the percentage inhibition efficiency $\left(\mathrm{IE}_{\mathrm{R}} \%\right)$ of hexadecylamine according to following expression:

$$
I E_{R} \%=\frac{R_{c t(i n h)}{ }^{-R c} t}{R_{c t(i n h)}} x 100
$$


Where, $R_{c t}$ and $R_{c t(i n h)}$ are the charge transfer resistance in absence and presence of different concentrations of inhibitor. The percentage inhibition efficiency $\left(\mathrm{IE}_{\mathrm{R}} \%\right.$ ) increases with increasing inhibitor concentrations and maximum value is $92.11 \%$ at $1000 \mathrm{ppm}$. Thus it indicates that hexadecylamine perform as good corrosion inhibitor for mild steel in $1.0 \mathrm{M}$ $\mathrm{HCl}$ medium.

Table 5. Impedance parameters and their corresponding inhibition efficiency in presence and absence of different concentrations of inhibitor at $298 \mathrm{~K}$ temperature

\begin{tabular}{ccccc}
\hline Inhibitor name & Conc., $\mathrm{ppm}$ & $\mathrm{R}_{\mathrm{ct}}, \Omega . \mathrm{cm}^{2}$ & $\mathrm{C}_{\mathrm{dl}}, \mu \mathrm{F} . \mathrm{cm}^{-2}$ & $\mathrm{IE}_{\mathrm{R}} \%$ \\
\hline & 0 & 43.64 & 321.20 & - \\
& 200 & 162.64 & 86.18 & 73.16 \\
Hexadecylamine & 400 & 310.17 & 45.19 & 85.93 \\
& 600 & 327.30 & 42.82 & 86.16 \\
& 800 & 386.30 & 36.28 & 88.70 \\
& 1000 & 553.18 & 25.33 & 92.11 \\
\hline
\end{tabular}

\section{Potentiodynamic polarization}

Potentiodynamic polarization curves for mild steel in $1.0 \mathrm{M} \mathrm{HCl}$ solution in absence and presence of different concentrations of hexadecylamine as corrosion inhibitor are shown in Figure 5. It can be seen from the figure that inhibitor effect both cathodic and anodic polarization curves or the inhibitor shifted the both cathodic and anodic branches of Tafel curve to lower value of current density. The inhibitor first adsorbed on mild steel surface then reduced the anodic dissolution and also retarted the hydrogen evolution reaction at cathodic side hence shows that hexadecylamine act as mixed type inhibitor. The polarization parameters values such as corrosion potential $\left(-\mathrm{E}_{\text {corr }}\right)$, anodic $\left(\beta_{\mathrm{a}}\right)$ and cathodic $\left(\beta_{\mathrm{c}}\right)$ Tafel constant, polarization resistance $\left(R_{p}\right)$ (that obtained from extraplotation of Tafel slope of curve), corrosion current density $\left(\mathrm{I}_{\text {corr }}\right)$ and inhibition efficiency $\left(\mathrm{IE}_{\mathrm{P}} \%\right)$ are illustrated in Table 6.

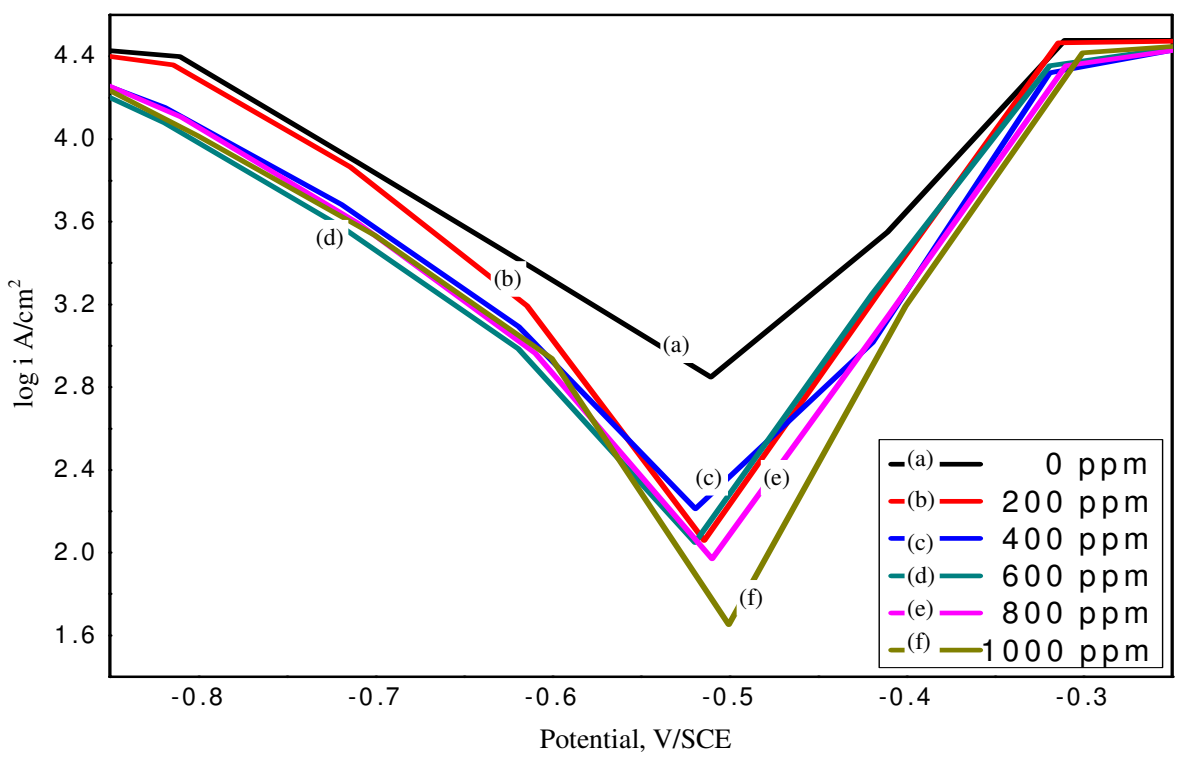

Figure 5. Tafel polarization curve for mild steel in $1.0 \mathrm{M} \mathrm{HCl}$ with presence or absence different concentration of hexadecylamine at $298 \mathrm{~K}$ 
The values of corrosion current density $\left(\mathrm{I}_{\text {corr }}\right)$ calculated by using following equation (Stern-Geary equation). The values of polarization resistance, cathodic and anodic Tafel constant are used to calculate the corrosion current $\left(\mathrm{I}_{\text {corr }}\right)$.

$$
I_{\text {corr }}=\frac{\beta_{a} x \beta_{c}}{2.303\left(\beta_{a}+\beta_{c}\right)} \times \frac{1}{R_{P}}
$$

Where, $R_{p}$ is the polarization resistance, $\beta_{a}$ and $\beta_{c}$ are the cathodic and anodic Tafel constant, respectively.

Table 6. Potentiodynamic polarization measurement for mild steel samples in $1.0 \mathrm{M} \mathrm{HCl}$ solution with and without different concentrations of inhibitor at $298 \mathrm{~K}$ temperature

\begin{tabular}{|c|c|c|c|c|c|c|c|}
\hline Inhibitor name & $\begin{array}{c}\text { Conc., } \\
\text { ppm }\end{array}$ & $\beta_{\mathrm{a}}, \mathrm{mV} \mathrm{dec}^{-1}$ & $\begin{array}{c}\beta_{\mathrm{c}}, \\
\mathrm{mV} \operatorname{dec}^{-1}\end{array}$ & $\begin{array}{c}\mathrm{R}_{\mathrm{p}}, \\
\Omega . \mathrm{cm}^{2}\end{array}$ & $\begin{array}{c}\mathrm{E}_{\text {corr }} \\
\mathrm{mV} \\
\text { vs.SCE }\end{array}$ & $\begin{array}{c}\mathrm{I}_{\text {corr }}, \\
\mu \mathrm{A} \mathrm{cm}^{-2}\end{array}$ & $\begin{array}{l}\mathrm{IE}_{\mathrm{p}} \\
\%\end{array}$ \\
\hline \multirow{6}{*}{ Hexadecylamine } & 0 & 582 & 1376 & 11.2 & -0.480 & 15.9 & - \\
\hline & 200 & 516 & 1227 & 59.3 & -0.476 & 2.65 & 83.33 \\
\hline & 400 & 490 & 1268 & 62.2 & -0.499 & 2.46 & 84.52 \\
\hline & 600 & 496 & 1207 & 69.7 & -0.477 & 2.19 & 86.22 \\
\hline & 800 & 499 & 1162 & 75.5 & -0.492 & 2.00 & 87.42 \\
\hline & 1000 & 442 & 1142 & 89.5 & -0.503 & 1.54 & 90.31 \\
\hline
\end{tabular}

Through the inspection of table it is found that the cathodic $\left(\beta_{a}\right)$, anodic $\left(\beta_{c}\right)$ Tafel constant values slightly change and polarization resistance $\left(R_{p}\right)$, inhibition efficiency values increases and corrosion current density $\left(\mathrm{I}_{\text {corr }}\right)$ decreases with increasing inhibitor concentration that confirm there is formation a protective thin layer film which reduced the corrosion process. This effect is also due to the inhibitor adsorb more strongly on steel surface as concentration of inhibitor high and which reduced both cathodic and anodic reaction on mild steel surface. The inhibition efficiency $\left(\mathrm{IE}_{\mathrm{p}} \%\right)$ for each concentrations of inhibitor are calculated by using following equation:

$$
I E_{p} \%=\left(1-\frac{I_{\text {corr }}^{i}}{I_{\text {corr }}{ }^{o}}\right) x 100
$$

Where, $I_{\text {corr }}{ }^{o}$ and $I_{\text {corr }}{ }^{i}$ are the corrosion current density without and with different concentrations of inhibitor, respectively. The maximum inhibition efficiency value of hexadecylamine found to be $90.31 \%$ and maximum reduction of corrosion current density $\left(\mathrm{I}_{\text {corr }}\right)$ found $1.54 \mu \mathrm{Acm}^{-2}$ at higher concentration of inhibitor (1000 ppm).

According to Ferreira ${ }^{60}$ (a) if the value of displacement in $\left(-E_{\text {corr }}\right)$ is higher than $85 \mathrm{mV}$ with respect to $\left(-\mathrm{E}_{\mathrm{corr}}\right)$, the inhibitor can be seen as anodic or cathodic type inhibitor and (b) if value of displacement in $\left(-E_{\text {corr }}\right)$ is lower than $85 \mathrm{mV}$, the inhibitor can be acts as mixed type inhibitor (both cathodic and anodic type). In present study the maximum displacement in $\left(-\mathrm{E}_{\text {corr }}\right)$ is $23 \mathrm{mV}$, which clearly indicates that hexadecylamine act as mixed type inhibitor ${ }^{61-63}$.

Inhibition efficiencies obtained from weight loss measurement $\left(\eta_{\mathrm{w}} \%\right)$ electrochemical; impedance spectroscopy $\left(\mathrm{IE}_{\mathrm{R}} \%\right)$ potentiodynamic polarization measurement $\left(\mathrm{IE}_{\mathrm{p}} \%\right)$ are in near about good reasonably agreement.

\section{Scanning electron microscope}

Surface study for corrosion of mild steel samples in $1.0 \mathrm{M} \mathrm{HCl}$ solution for immersion period of 24 hours at 298, 308 and $318 \mathrm{~K}$ temperatures in absence and presence of hexadecylamine are shown in Figures $6 \mathrm{a}, \mathrm{b}$. 
Figures show that in absence of inhibitor the surface of sample was completely damaged and in presence of inhibitor sample surface was almost unaffected by corrosion. It exhibit that there is a formation of thin protective film on mild steel surface which protect against corrosion.
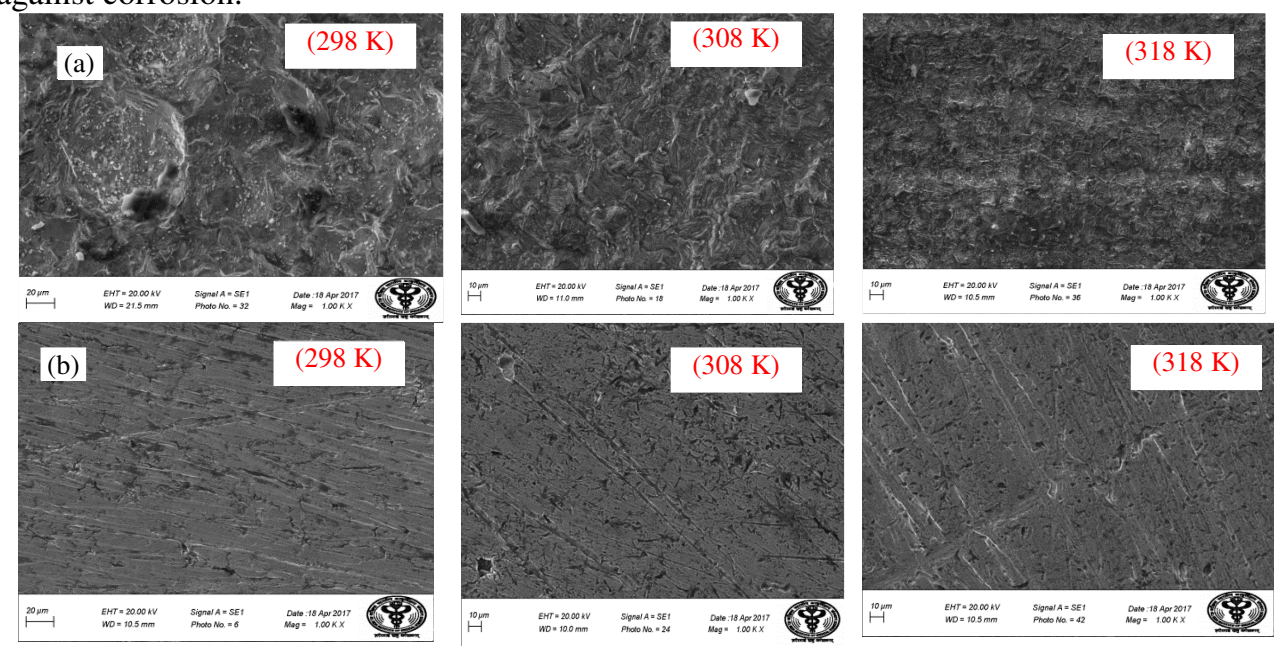

Figures 6a,b. SEM images of mild steel surface at different temperatures (a) immersed for $24 \mathrm{~h}$ in blank $1.0 \mathrm{M} \mathrm{HCl}$ and (b) with $1000 \mathrm{ppm}$ concentrations of hexadecylamine

\section{Conclusion}

Weight loss study shows that the inhibition efficiency of hexadecylamine increases with increasing concentration. From the electrochemical impedance measurement it can be seen that when inhibitor concentration increasing charge transfer resistance increases and double layer capacitance decreases. Hence percentage inhibition efficiency increases. By potentiodynamic polarization it showed that hexadecylamine is a mixed type corrosion inhibitor. Surface study show that there is formation of protective layer of inhibitor on mild steel surface

\section{References}

1. Melchers R E and Jeffery R, Corros Rev., 2005, 1, 84.

2. Melchers R E and Jeffery R, Corros Rev., 2005, 6, 297.

3. Ostovari A, Hoseinieh S M, Peikari M, Shadizadeh S R, Hashemi S J, Corros Sci., 2009, 51(9), 1935-1949; DOI:10.1016/j.corsci.2009.05.024

4. Bayol E, Gürten T, Gürten A A and Erbil M, Mater Chem Phys., 2008, 112(2), 624630; DOI:10.1016/j.matchemphys.2008.06.012

5. Avci G, Mater Chem Phys., 2008, 112(1), 234-238; DOI:10.1016/j.matchemphys.2008.05.036

6. Lagrene M, Mernari B, Bouanis M, Traisnel M and Bentiss F, Corros Sci., 2002, 44(3), 573-588; DOI:10.1016/S0010-938X(01)00075-0

7. Bentiss F and Lagrene'e M, J Mater Environ Sci., 2011, 2(1), 13-17.

8. Zhang F, Tang Y, Cao Z, Jing W, Wu Z and Chen Y, Corros Sci., 2012, 61(1), 1-9; DOI:10.1016/j.corsci.2012.03.045

9. Nataraja S E, Venkatesha T V, Manjunatha K, Poojary B, Pavithra M K and Tandon H C, Corros Sci., 2011, 53(8), 2651-2659; DOI:10.1016/j.corsci.2011.05.004

10. Li W, Zhao X, Liu F and Hou B, Corros Sci., 2008, 50(11), 3261-3266; DOI:10.1016/j.corsci.2008.08.015 
11. Zhang S, Tao Z, Li W and Hou B, Appl Surf Sci., 2009, 255(15), 6757-6763; DOI:10.1016/j.apsusc.2008.09.089

12. Hasanov R, Bilge S, Bilgiç S, Gece G and Kılıç Z, Corros Sci., 2010, 52(3), 984-990; DOI:10.1016/j.corsci.2009.11.022

13. Qurashi M A, Khan M A W, Jamal D, Ajmal M, Muralidharan S and lyer S V K, Brit Corros J., 1997, 32, 72.

14. Mernari B, Attari H Ei, Trainsel M, Bentiss, Lagrenee M, Corros Sci., 1998, 40(2-3), 391-399; DOI:10.1016/S0010-938X(97)00142-X

15. Bentiss F, Lagrenee Traisnel, Traisnel M M and Hornez J C, 1999, 41(4), 789; DOI:10.1016/S0010-938X(98)00153-X

16. Azhar M.El, Mernari B, Traisnel M, Bentiss L and Lagrenee F M, Corros Sci., 2001, 43(12), 2229-2238; DOI:10.1016/S0010-938X(01)00034-8

17. Dean Jr S W, Derby R and Von dem bussche G T, Materials Performance, 1981, 20(12), 47-51.

18 Riggs O L Jr, Corrosion Inhibitors, Second Ed., Nathan C C, Houston, TX, 1973

19. Hosseini S M A and Azimi A, Corros Sci., 2009, 51(4), 728-732;

DOI:10.1016/j.corsci.2008.11.019

20. Doner A and Kardas G, Corros Sci., 2011, 53(12), 4223-4232;

DOI:10.1016/j.corsci.2011.08.032

21. Deng Li X and Fu S H, Corros Sci., 2011, 53(1), 302-309;

DOI:10.1016/j.corsci.2010.09.036

22. Bentiss F, Traisnel M, Gengembre L and Lagrenee M A, Appl Surf Sci., 1999, 152(3-4), 237-249; DOI:10.1016/S0169-4332(99)00322-0

23. Hegazy M A, Abdallah M, Awad M K and Rezk M, Corros Sci., 2014, 81, 54-64; DOI:10.1016/j.corsci.2013.12.010

24. Rudresh H B and Mayanna S M, J Electrochem Soc., 1977, 124(3), 340-342; DOI:10.1149/1.2133301

25. Lece H D, Emregul K C and Atakol O, Corros Sci., 2008, 50(5), 1460-1468; DOI:10.1016/j.corsci.2008.01.014

26. Samiento-Bustos E, Gonzalez Rodriguez J G, Uruchurtu J, Dominguez-Patino G and Salinas-Bravo V M, Corros Sci., 2008, 50(8), 2296-2303;

DOI:10.1016/j.corsci.2008.05.014

27. Sahin M, Gece G, Karci F and Bilgic S, J Appl Electrochem., 2008, 38(6), 809-815.

28. Gece G, Corros Sci., 2008, 50(11), 2981-2992; DOI:10.1016/j.corsci.2008.08.043

29. Badawy W A, Ismail K M and Fathi A M, Electrochim Acta, 2006, 51(20), 41824199; DOI:10.1016/j.electacta.2005.11.037

30. Abdallah M, Helal E A and Fouda A S, Corros Sci., 2006, 48(7), 1639-1654; DOI:10.1016/j.corsci.2005.06.020

31. Fouda A S, Abdallah M and Attia A, Chem Eng Commun., 2010, 197(8), 1091-1108; DOI:10.1080/00986440903412944

32. Kumar H and Kumari M, Elix Corros Dye, 2016, 93, 39321.

33. Kumar H and Kumari M, Int J Chemi Studies., 2016, 4(2), 32-39.

34. Kumar H and Yadav V, Res J Chem Sci., 2016, 6(1), 53-60.

35. Saini V and Kumar H, Res J Chem Sci., 2014, 4(6), 45-53.

36. Ahamad I, Prasad R and Quraish M A, Corros Sci., 2010, 52(9), 3033-3041; DOI:10.1016/j.corsci.2010.05.022

37. Kumar H, Om H, Kumar P, Vikas and Anjoo, Elix Corros Dye, 2016, 97, 42060.

38. Uhlig H H and Revie R W, Corrosion and Corrosion Control, Wiley, New York, $1985,270$. 
39. Rozenfeld I L, In Corrosion Inhibitors (Edited by I L Rozenfeld), McGraw-Hill, New York, 1981, 109.

40. Gardner G, In Corrosion Inhibitor (Edited by C C Nathan), NACE, Houston, 1973, 156-172.

41. Schmitt G, Bri Corros J., 1984, 19, 165.

42. Braun R D, Lopez E E and Voltmer D P, Corros Sci., 1993, 34(8), 1251-1257; DOI:10.1016/0010-938X(93)90085-U

43 Shen H W and Smialowskya Z S, Corros., 1989, 45(9), 720-725

44. Om H, Kumar H, Kumar P, Vikas and Bala A, Der Phar Chemi., 2016, 8(19), 268-278.

45. Oguzie E E, Unaegbu C, Ogukwea C N, Okolue B N and Onuchuku A I, Mater Chem Phys., 2004, 84(2-3), 363-368; DOI:10.1016/j.matchemphys.2003.11.027

46. Li X H, Deng S D and Fu H, Corros Sci., 2012, 62, 163-175;

DOI:10.1016/j.corsci.2012.05.008

47. Bobina M, Kellenberger A, Millet J P, Muntean C and Vaszilcsim N, Corros Sci., 2013, 69, 389-395; DOI:10.1016/j.corsci.2012.12.020

48. Flis J and Zakroczymski T, J Electrochem Soc., 1996, 143(8), 2458-2464; DOI:10.1149/1.1837031

49. Khamis E, Bellucci F, Latanision R M and El-Ashry E S H, Corros., 1991, 47(9), 677-686; DOI:10.5006/1.3585307

50. Cano E, Polo J L, Iglesia A La and Bastidas J M, Adsorption, 2004, 10(3), 219-225; DOI:10.1023/B:ADSO.0000046358.35572.4c

51. Bentiss F, Lebrini M and Lagrenee M, Corros Sci., 2005, 47(12), 2915-2931; DOI:10.1016/j.corsci.2005.05.034

52. Khamis A, Saleh M M, Awad M I and El-Anadouti B E, Corros Sci., 2013, 74, 8391; DOI:10.1016/j.corsci.2013.04.026

53. Brinic S, Grubac Z, Babic R and Metikos-Hukovic M, in: $8^{\text {th }}$ Eur Symp Corros Inhib., 1995, 1, 197.

54. Geler E and Azambuja D S, Corros Sci., 2000, 42(4), 631-643; DOI:10.1016/S0010938X(99)00080-3

55. Bouklah M, Benchat N, Hammouti B, Aouniti A and Kertit S, Lett Mater., 2006, 60(15), 1901-1905; DOI:10.1016/j.matlet.2005.12.051

56. Cao C N and Zhang J Q, Science Press, Beijing, 2002, 172 (in Chinese).

57. Behpour M, Ghoreishi S.M, Mohammadi N and Soltani N M, Corros Sci., 2010, 52(12), 4046-4057; DOI:10.1016/j.corsci.2010.08.020

58. Qu Q, Jiang S A, Bai W and Li L, Electrochim Acta, 2007, 52(24), 6811-6820; DOI:10.1016/j.electacta.2007.04.114

59. Daoud D, Douadi T, Issaadi S and Chafaa S, Corros Sci., 2014, 79, 50-58;

DOI:10.1016/j.corsci.2013.10.025

60. Ferreira E S, Giancomelli C, Giacomelli F C and Spinelli A, Mater Chem Phys., 2004, 83(1), 129-134; DOI:10.1016/j.matchemphys.2003.09.020

61. Hegazy M A, Hasan A M, Emara M M, Bakr M F and Youssef A H, Corros Sci., 2012, 65, 67-74; DOI:10.1016/j.corsci.2012.10.002

62. Deng S, Li X and Hui F, Corros Sci., 2011, 53(11), 3596-3602;

DOI:10.1016/j.corsci.2011.07.003

63. Saleh M M and Atia A A, J Appl Electrochem., 2006, 36, 899;

DOI:10.1007/s10800-006-9147-6 